日臨外会誌 $65(6) ， 1695-1700 ， 2004$

症例

術中高血圧をきたした後腹膜パラガングリオーマの 1 例

横浜市立大学市民総合医療センター消化器病センター, 同 病理学部*

高川亮大島貴羽鳥慎祐國崎主税

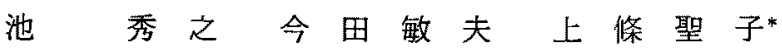

45歳, 男性. 人間ドックの腹部エコー検查にて後腹膜の腫痛を指摘され, 当院を受猃 した。血液生化学検査では血中ノルアドレナリンとドーパミンの上昇を認めた. CT では

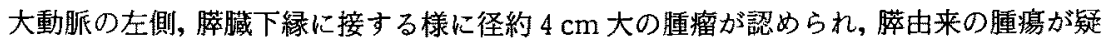
われたが, 造影 MRI で膵との境界が確認され否定的となった。血管造影では第12肋間動

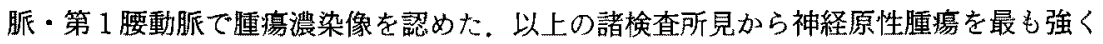
疑い，手術を施行した。術中に著明な血圧の上昇を認め，一時手術を中断したが，降圧

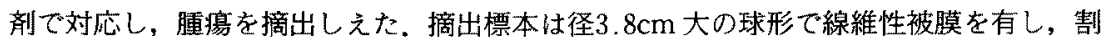

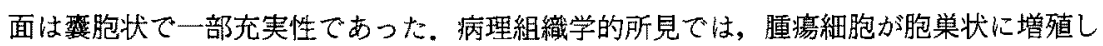
ており,クロモグラニン A が陽性で, S-100陽性の特徵的な支持細胞が確認されることよ りパラガングリオーマと診断した。良悪性の診断では, Ki-67陽性細胞が10\%以下である ことより良性と診断した，後腹膜パラガングリオーマは比較的稀な疾患であり文献的考 察を加えて報告する。

索引用語：後腹膜腫煬, パラガングリオーマ

\section{緒 言}

後腹膜パラガングリオーマは後腹膜隀瑒の $1.8 \%$ と 稀な腫湯であり，われわれの調べえた範囲では，本邦 では106例の報告に過ぎない.腹部腫瘤で気付かれるこ とが多いが，機能性のものでは，高血圧などの症状を 呈し発見されることがある，今回われわれは術前無症 状であったにも関わらず，術中高血圧をきたした後腹 膜パラガングリオーマを経験したので文献的考察を加 えて報告する。

患者：45歳，男性.

$$
\text { 症例 }
$$

主訴：なし.

家族歴：特記すべきことなし。

既往歴：5歳時アデノイドにて手術。22歳虫垂炎で 手術. 44歳より痛風で内服治療中.

現病歴：人間ドックにて腹部エコー施行し，腹部腫 瘤を指摘され，当院紹介受診とした。

2003 年 10 月 31 日受付 2004 年 3 月10日採用 〈所属施設住所〉

T232-0024 横浜市南区涌舟町 4-57
現症: 身長 $174.4 \mathrm{~cm}$, 体重 $79.8 \mathrm{~kg}$, 体温 $35.6^{\circ} \mathrm{C}$, 血 圧 $130 / 80 \mathrm{mmHg}$, 脈拍62回 (整). 胸部聴診上異常は認 めなかった，腹部は平坦・軟で，腫瘤・リンパ節触知 しなかった。

入院時検查所見：血中ノルアドレナリンドーパミ ンの高值を認める以外, 腫掦マ一カーを含め血液生化 学所見に異常は認めなかった(表 1 )。

腹部 $\mathrm{CT}$ 検査 : 上腸間膜動脈の根部の高さ大動脈の 左側に, 径 $4 \times 3 \mathrm{~cm}$ 大の周囲に強い造影を認める内

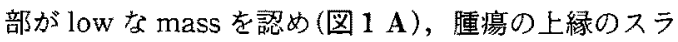
イスで副腎と別なものであることを確認できた（図 1

\section{表 1 血液生化学所見}

\begin{tabular}{lr|lr}
\hline $\mathrm{WBC}$ & $7,900 / \mathrm{ul}$ & Glu & $90 \mathrm{mg} / \mathrm{dl}$ \\
$\mathrm{Hb}$ & $13.9 / \mathrm{dl}$ & CRP & $0.1 \mathrm{mg} / \mathrm{dl}$ \\
$\mathrm{Plt}$ & $243 \times 103 / \mathrm{ul}$ & CEA & $2.5 \mathrm{ng} / \mathrm{ml}$ \\
$\mathrm{TP}$ & $7.5 \mathrm{~g} / \mathrm{dl}$ & $\mathrm{CA} 19-9$ & $<1 \mathrm{U} / \mathrm{ml}$ \\
$\mathrm{Alb}$ & $5.0 \mathrm{~g} / \mathrm{dl}$ & $\mathrm{AFP}$ & $3 \mathrm{ng} / \mathrm{ml}$ \\
$\mathrm{BUN}$ & $12 \mathrm{mg} / \mathrm{dl}$ & $\mathrm{NSE}$ & $7.6 \mathrm{ng} / \mathrm{ml}$ \\
$\mathrm{Cr}$ & $0.83 \mathrm{mg} / \mathrm{dl}$ & クルアドレ+リン & $0.96 \mathrm{ng} / \mathrm{ml} \uparrow$ \\
$\mathrm{AST}$ & $21 \mathrm{U} / 1$ & ドーパミン & $0.04 \mathrm{ng} / \mathrm{ml} \uparrow$ \\
$\mathrm{ALT}$ & $251 \mathrm{U} / 1$ & 尿中VMA & $0.14 \mathrm{ng} / \mathrm{ml}$ \\
\hline
\end{tabular}



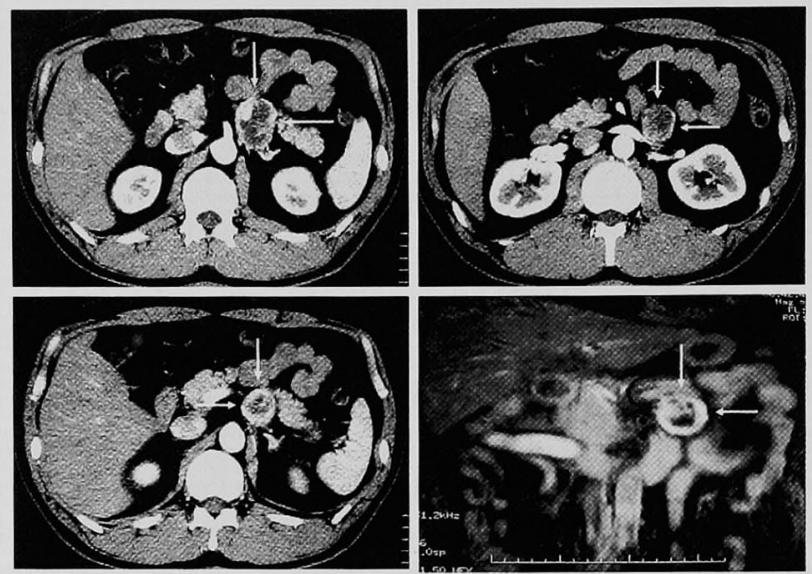

图 1 造影 CT：A) 大動脈の左側に $4 \times 3 \mathrm{~cm}$ 大の周囲が強く造影さ れる内部が low な mass を認めた。Ｂ）腫瘍上緑のスライスでは, 副腎との境界は明膫であった，C）腫富下緑のスライスでは，左腎 静脈に接するように腫堭は存在していた，D ) MRIT2強調画像前額 断。膵臓との境界は明膫であった。

\begin{tabular}{l|l}
$\mathrm{A}$ & $\mathrm{C}$ \\
\hline $\mathrm{B}$ & $\mathrm{D}$
\end{tabular}

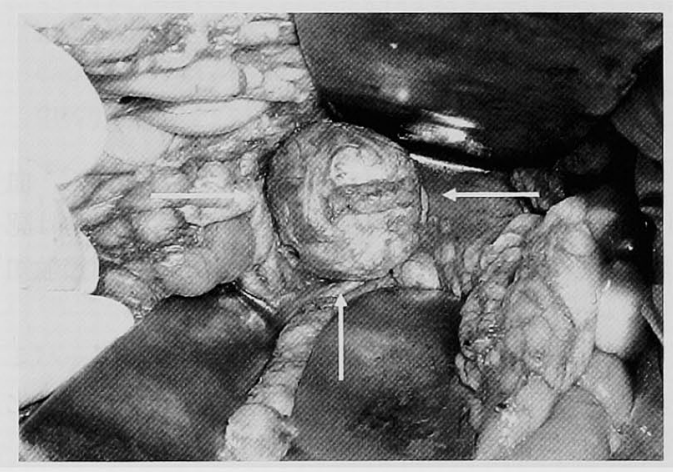

図 2 術中所見：血管に富む $4 \mathrm{~cm}$ 大の弾性硬な腫瘍を 認めた。

B). 腫場の下緑のスライスでは, 左腎静脈に接してい るように見えた（図１C）。

MRIT2 強調画像前額断：膵臓との境界は明瞭であ り膵由来の腫瘍は否定的であった（図 $1 \mathrm{D}$ ).

腹部血管造影：左第12肋間動脈, 第 1 腰動脈で尰湯 濃染像を認めた.

以上の諸検査所見より後腹膜神経原性腫場を最も強 く疑い，腫瘍摘出術を施行した。

手術所見：正中切開にて開腹すると病変はTreitz 勒帯の左側, 後腹膜下に, $4 \mathrm{~cm}$ 大の弾性硬の腫瘤とし
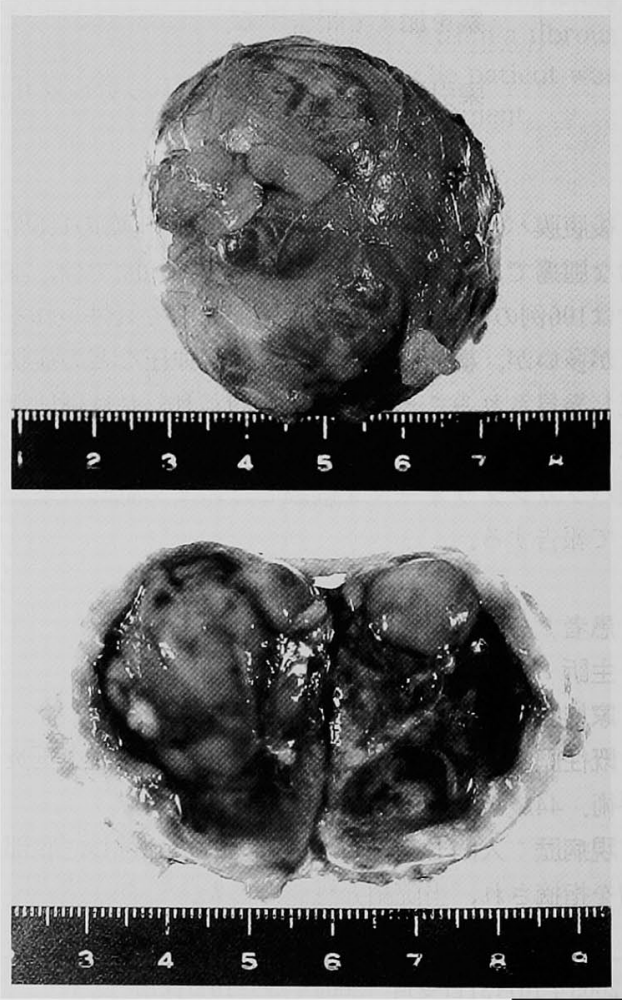

図 3 摘出標本 : 大きさ $3.8 \times 3.5 \mathrm{~cm}$ の線維性被膜

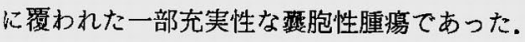




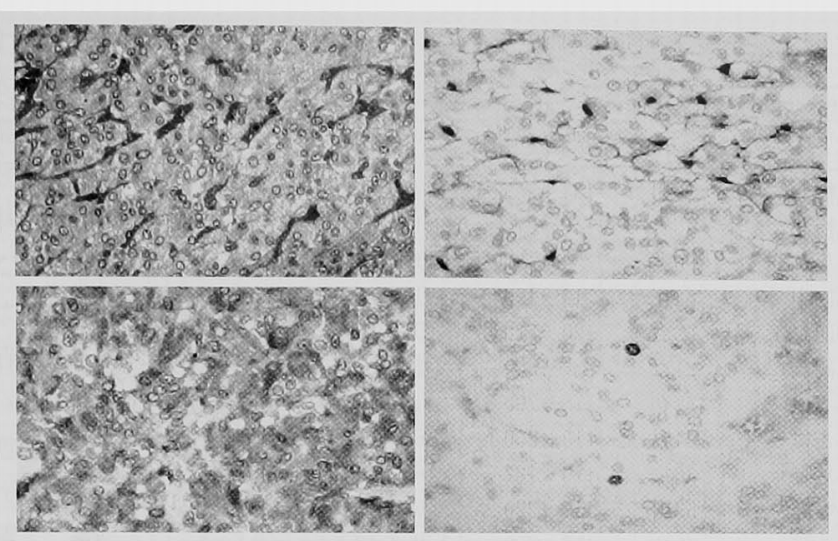

図 4 病理組織所見：A）HE 染色. 腫瘍細胞の胞巣状の増殖がみられ た $(\times 20)$. B ) クロモグラニン A では細胞全体が陽性に染まってい た $(\times 40)$ ，C）S-100染色にて，支持細胞が陽性に染まっていた（X 40).D）Ki-67陽性細胞は $10 \%$ 以下であった $(\times 40)$.

$$
\begin{array}{l|l}
\mathrm{A} & \mathrm{C} \\
\hline \mathrm{B} & \mathrm{D}
\end{array}
$$

表 2 後腹膜 paraganglioma 本邦報告106例の検討

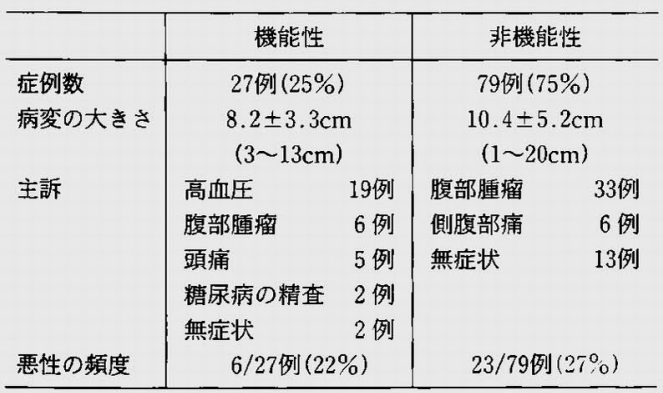

て触診した．結腸脾彎曲を脱転し，後腹膜を剥離した。 腫瘍は大動脈の左側, 膵下面, 左腎動脈に接しており, 副腎とは別の組織であった．被膜は血管に富んでいた が，周囲への浸潤を認めず，剝離は容易であった。し かし, 手術操作中に, $262 / 118 \mathrm{mmHg}$ と著明な高血圧を 認めたため, 一時手術を中断し, 塩酸二カルジピン静 注と, ニトログリセリンの持続静注にて, 血圧をコン トロールし, 手術を続行, 腫湯を摘出しえた（図 2 ).

摘出標本：大きさ $3.8 \times 3.5 \mathrm{~cm}$ の線維性被膜に覆わ れており (図 $3 \mathbf{A}$ ), 割面は一部充実な部分を含む㪛胞 性の腫湯であった (図 $3 \mathrm{~B}$ ).

病理組織所見：HE 染色では，好塩基性の顆粒状の 胞体と円型核を有する腫湟細胞が胞巣状に増殖してお り (図 $4 \mathrm{~A}$ ), 免疫染色では, クロモグラニン A が陽性 で神経原性腫瘍と訬断された（図４B）。またS-100陽
性の特徴的な支持細胞の所見を䜑め (図 $4 \mathrm{C}$ ), 以上よ りパラガングリオーマと診断した. 良悪性の診断では, 核小体は明暸で，mitosis は認められず，Ki-67陽性細 胞は $1 \%$ 以下であることから，良性の可能性が高いと 判断した（図 4 D).

術後経過は良好で術後 8 日目に軽快退院した。

\section{考察}

後腹膜腫瘍は比較的稀な疾患で全腫瘍に占める割合 は0.2\%といわれ",さらにこの中でパラガングリオー マの占める割合は $1.8 \%$ とされる2).

パラガングリオーマは, 神経提由来の自律神経系の 細胞から発生すると考えられる一連の腫演の総称であ る. 副腎髄質原発のものが褐色細胞腫と呼ばれ, 副腎 以外の傍神経節から生じたものがパラガングリオーマ と呼ばれている3!.

川原田ら は)は, パラガングリオーマをクロム親和性 の有無と内分泌症状による機能性・非機能性により分 類した，機能性・非機能性で分類する場合では，症候 的に分けるのか内分泌的に分けるのかでその分類が瞹 昧となるが，諸家の報告を見ると，高血圧を呈するな ど症候的なものを機能性に分ける場合が多くみられ る5!

後腹膜パラガングリオーマは, 血液生化学検査所見 と画像検査所見, 病理組織学的所見により最終診断さ れる。

血液生化学検査所見では, 血中カテコラミン, 尿中 VMAの高值がみられることが多い. 
表 3 郝中高血圧をきたした paraganglioma15症例

\begin{tabular}{|c|c|c|c|c|c|}
\hline 報告省 & 年齢・性 & $\begin{array}{l}\text { 高血玨 } \\
\text { 術前 術中 }\end{array}$ & $\begin{array}{c}\text { 犬きさ } \\
(\mathrm{cm})\end{array}$ & 肉眼像 & 血中カテコラミン値 \\
\hline '84梅北 & 39男 & $124 \rightarrow$ 高血圧 & $7 \times 5$ & cystic & 未检查 \\
\hline '84梅北 & 46男 & $140 \rightarrow 270$ & $11 \times 9$ & cystic & 末检查 \\
\hline '85小林 & $80 女$ & $134 \rightarrow$ 高血圧 & $11 \times 10$ & mixed & 未検査 \\
\hline '88田中' & $64 女$ & $112 \rightarrow 190$ & $12 \times 11$ & cystic & 未検查 \\
\hline 89西售 & 62 男 & $120 \rightarrow 220$ & $9 \times 8$ & mixed & 高值 \\
\hline '91高橋 & 21女 & $92 \rightarrow 180$ & 約7.5 & mixed & 高値 \\
\hline 93二村 & 42女 & $118 \rightarrow 200$ & $13 \times 13$ & solid & 未楧查 \\
\hline '93吉村 & 64男 & $110 \rightarrow 200$ & $6 \times 5$ & solid & 高値 \\
\hline '93星野' & 36女 & $110 \rightarrow 182$ & $6 \times 4$ & solid & 未検查 \\
\hline '96塩沢 & 53 男 & $117 \rightarrow 220$ & $7 \times 5$ & solid & 正常 \\
\hline '96西澤 & $49 女$ & $118 \rightarrow 200$ & $3.3 \times 2.5$ & solid & 高值 \\
\hline '99丸山 & 68女 & & & & 高値 \\
\hline ’00千住 & 58 女 & $114 \rightarrow 208$ & $13 \times 13$ & cystic & 高值 \\
\hline '01松浦 & 60 女 & 146一高血压 & $11 \times 10$ & mixed & 正常 \\
\hline '03自䨐例 & 45男 & $130 \rightarrow 256$ & $3.8 \times 3.5$ & cystic & 高値 \\
\hline
\end{tabular}

画像検查所見では，超音波・CT・MRI で血管の豊富 な充実性腫瘍として描出されることが多いほか, 出 血・壊死による蹒胞状変化を伴うことも多い6). また特 異性が高いという点から, ${ }^{13 \mathrm{I}} \mathrm{I}$ Meta-indobenzylguanidine によるシンチグラフィがパラガングリオー マの診断に有用とされている゙。.

病理組織学的所見では, 基本的には副腎髄質類似の 構造を示し, 腫掦細胞の胞巣状集合体の周囲を支持細 胞と毛細血管が取り囲むZ Zellballen と呼ばれる配列 をとる.さらに非腫演部に副腎組織が認められないこ と,またクロモグラニンAなどの免疫染色が陽性であ ること, S-100陽性の特徽的な支持細胞が存在するこ とによって確定診断される. 病理組織学的悪性の評価 は mitosis の有無, 血管侵襲の有無や Ki-67免疫染色 の割合などで評価される8).

予後については，組織学的には良性と診断された症 例でも, 䠛床的に切除後長期間を経て再発, 転移, 死 亡例が報告されており，その長期的フォローが必要で あると考えられているき. また悪性のものでは，その転 移率が20～50\%と高率であることから慎重な経過観察 が必要とされる ${ }^{10}$. 転移部位としては, 肝臓, 肺, 骨な どが報告されて扔り，このことから血行性転移が示唆 される。

治療についてはCVD療法 (cyclophosphamide, vincristine, dacarbazin）が有効であったとの報告も ある゙が，一般には化学療法は有用でないといわれて いる. 外科的切除は，良悪性を含め完全切除例で 5 年
生存率が75\%，非完全切除例で19\%であることより， 治療の第一選択となる ${ }^{123}$.

後腹膜パラガングリオーマの報告例はわれわれが調 ベえた限りでは，本邦では106例報告ある。機能性は27 例，25\%で，非機能性は79例，75\%である(表 2)。病 変の大きさは機能性と非機能性で有意差を認めない が, 非機能性では機能性では認められない最大径 $15 \mathrm{~cm}$ 以上の症例が多数例で認められ，腹部腫瘤で気付かれ る例が多い，それに対して，機能性では高血圧で気付 かれる症例が多い. 本症例は術前血液生化学検查で, 血中カテコラミンの上昇を認めたため機能性に分類さ れるが，術前は無症状であった，悪性例は29例，27\% に認められたが，機能性，非機能性に頻度の差を認め ず，術前の機能性，非機能性に関わらず腫場摘出が必 要であると考えられた。

術中高血圧をきたしたパラガングリオーマの報告例 は本邦では本症例を含めて15例であり，その症例の大 部分は術前のホルモン検査にてノルアドレナリンの高 值を認めている(表 3 )。ノルアドレナリンの高値を認 めなかった正常例もあるが，木ルモン分泌が閒欠的な 腫晹もあることが報告されて扔り，また門脈経由での 肝臓での不活化, 持続的分泌で生体の感受性が低下し

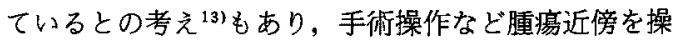
作して初めて血圧上昇などホルモン症状を呈すること があることが考えられる，本症例は術前ノルアドレナ リン高值であったが，症状は呈しておらず，手術中に 著明なホルモン症状を呈したものであった。 
後腹膜パラガングリオーマは, 手術死亡例が $5.5 \% に$

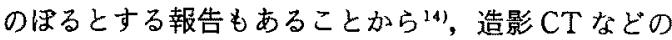
画像検査にて後腹膜腫湯が疑われた際には，ホルモン 检查を追加して調べておくことが大切である.しかし， ホルモン検查正常例の中にも手術中に予期せず血圧上 昇をきたす場合があることから，後腹膜パラガングリ オーマが疑われた際には，外科的切除に際しては，腫 瘍の drainage vein の結禁を先行して行うことや，腫 瘍本体を強く王迫しないといった手術操作の工夫と, 麻酔科と連携した手術進行を行うといった十分な配慮 が必要であると考えられた。

\section{結語}

今回われわれは無症状であったが，術中高血压をき たした後腹膜パラガングリオーマを経験したので文献 的考察を加え，症例報告した。

\section{文 献}

1) Pack GT, Taban EJ : Primary retroperitoneal tumors: A study of 120 cases. Int Abst Surg $99: 209-231,1954$

2) Whalen RK, Althausen AF, Daniels GH : Extra -adrenal pheochromocytoma. J Urol 147:110,1992

3) Pick L : Das ganglioma embryonale sympathy cum. Bclin Klin Wchnschr 16:67, 1912

4) 川原田嘉文, 吉村明文, 西田正方他: 肝癌の疑わ れた後腹膜 paraganglioma の 1 治験例. 日臨外 会誌 $41: 1074-1080,1980$

5）西塚 至，高橋正純，池 秀之他：術中高血圧を 呈した左腹腔神経節原発パラガングリオーマの 1 例。日臨外会誌 $59: 2394-2399,1998$

6）寉田徹，石山 暗，山岡博之他：検猃で発見さ
れた後腹膜 paraganglioma の 1 例. 日踇外会誌 $58: 900-904,1997$

7) Nguyen $\mathrm{HH}$, Proye CAG, Carnaille $\mathrm{B}$, et al : Tumor size: The only predictive factor for ${ }^{131} \mathrm{I}$ MIDG uptake in phaeochromocytoma and paraganglioma. Aust NZ surg 69:350-353, 1999

8) Clarke MR, Weyant RJ, Wtson CG, et al : Prognostic markers in pheochromocytoma. Hum Pathol 29:522--526, 1998

9) 遠藤秀彦, 佐藤武彦, 石川 徹他：術後 7 年で肝 転移をきたした後腹膜 paraganglioma の 1 例. 日踟外会誌 $62 ： 2303-2306,2001$

10) O'Riordain RI, Young WF Jr, Grant CS, et al : Clinical spectrum and outcome of functional extraadrenal paraganglioma. World J Surg $20: 912-922,1996$

11) Sclafani LM, Woodruff JM, Brennann MF : Extraadrenal retoperitoneal paragangliomas: natural history and response to treatment. Surgery 108 : 1124-1130, 1990

12) Averbach SD, Steakley CS, Young SC, et al: Malignant pheochromocytoma Effective treat. ment with a combination of cyclo phosphamide, vindesine and dacarbazine. Ann Intern Med 109:267-273, 1988

13）塩㩐俊一, 土屋嘉昭，田中乙雄他：術中高血圧を 呈した後腹膜 paraganglioma 1 例. 日臨外会 誌 $57: 3078-3081,1996$

14）佐藤辰男, 大石誠一，岩岡大輔他：褐色細胞腫. 日臨41（春季増刊）：879-890，1983 


\title{
A SURGICAL CASE OF RETROPERITONEAL PARAGANGLIOMA CAUSING INTRAOPERATIVE HYPERTENSION
}

\author{
Ryo TAKAGAWA, Tsukasa OSHIMA, Shinsuke HATORI, Chikara KUNISAKI, \\ Hideyuki IKE, Toshio IMADA and Seiko KAMIJO* \\ Gastroenterological Center and Department of Pathology*, Yokohama City University Medical Center
}

A 45-year-old man was seen at the hospital because of a retroperitoneal tumor detected by abdominal ultrasonography at a clinical survey. On blood biochemical tests, elevated blood levels of noradrenalin and dopamine were noted. Abdominal CT scan revealed a tumor about $4 \mathrm{~cm}$ in diameter located on the left side of the aurta which appeared to be adjacent to the inferior margin of the pancreas, suggesting a tumor arisen from the pancreas. However, enhanced magnetic resonance imaging scan demonstrated the border with the pancreas, and a possibility of a pancreatic tumor was ruled out. Angiography showed accumulation of contrast material in the $12^{\text {th }}$ intercostal and the first lumber arteries. From these findings we thought that neurogenic tumor was most likely and performed surgery. During surgery, prominent elevation in blood pressure occurred. So we suspended the operation, dealt with hypertension with a depressor, and successfully removed the tumor. The removed tumor was $3.8 \mathrm{~cm}$ in diameter and spherical in shape and had a fibrous capsule, of which section was cystic with a solid part. Histopathologically tumor cells proliferated in honeycomb pattern, and characteristic sustentacular cells which were chromoglanine A and S-100 positive were identified. Accordingly paraganglioma was diagnosed. As for differential diagnosis between benign or malignant lesion, the tumor was dignosed as benign because $\mathrm{Ki}-67$-positive cells were less than $10 \%$.

This case of retroperitoneal paraganglioma which is a relatively rare entity is presented, together with some bibliographical comments. 